\title{
ENDEMONIADOS, IMPOSTORES 0 ENFERMOS. DISCERNIMIENTO DE ESPÍRITUS EN LOS TRATADOS DEMONOLÓGICOS DE LA INGLATERRA REFORMADA (1580-1630)
}

\author{
Demoniacs, Frauds or III. Discernment of Spirits in Reformed \\ England Demonological Treatises (1580-1630)
}

\author{
Agustín Méndez \\ mendezagustin@live.com.ar \\ Universidad de Buenos Aires. Argentina \\ Fecha de recepción: 19/08/2020 \\ Fecha de aceptación: 20/02/2021
}

Resumen: A partir de un análisis de los tratados sobre brujería publicados por teólogos y ministros protestantes, el presente artículo se propone estudiar las particularidades del discernimiento de espíritus en relación al problema de la posesión espiritual en la Inglaterra de finales del siglo XVI y comienzos del XVII. En este tipo de literatura teológica, los padecimientos de los posesos eran interpretados de tres maneras diferentes: como el resultado de una invasión demoníaca, como una enfermedad de origen natural o como un fingimiento. De esta manera, se propone como hipótesis que existía un explícito rechazo a la posibilidad de que los cuerpos poseídos fuesen anfitriones de la divinidad o de alguno de sus ángeles, algo comúnmente aceptado dentro del paradigma del discernimiento contemporáneo. Esta negativa sería el resultado del modo en que el discurso demonológico inglés entendía áreas más amplias de la teología como la Providencia y su relación con el colectivo humano, los milagros y los carismas, y la santidad, así como también del carácter inherentemente polémico de la tratadística contra la brujería del periodo.

Palabras clave: discernimiento de espíritus; posesión; Inglaterra; demonología; protestantismo.

Abstract: Through an analysis of witchcraft treatises penned by Protestant theologians and ministers, this article studies the particularities of the discernment of spirits and its relations with 
the problem of spiritual possession in England between the end of the Sixteenth and the beginning of the Seventeenth century. In these documents, the suffering of the possessed were interpreted in three different ways: as the result of demonic infestation, as a natural illness, or as a fraud. In this way, the hypothesis is that English demonologists explicitly rejected the possibility of divine or angelic possession, something typically accepted by contemporaneous discernment paradigms. This negative could be considered as the byproduct of the way in which these authors understood broader theological issues, such as Providence and its relations with humankind, miracles, charisma, and sanctity. It could also be considered as a consequence of the inherently polemical nature of anti-witchcraft treatises.

Keywords: discernment of spirits; possession; England; demonology; Protestantism.

Sumario: 1. Introducción. 2. El discernimiento de espíritus: Pablo, Gerson y un jesuita inglés 3. Discernir las posesiones en las demonologías inglesas. 4. El marco teológico. 5. Conclusiones. 6. Referencias bibliográficas.

\section{INTRODUCCIÓN}

Desde hace más de veinte años, la historiografía de la caza de brujas tempano moderna atraviesa su edad de oro. Año tras año, la cantidad, variedad y jerarquía de los trabajos académicos la mantiene como uno de los objetos de estudio más populares entre los especialistas del periodo, tanto en Europa como en América (Boyer y Nissembaum 1993, Norton, 2003; Behringer, 2004; Levack, 2006; Campagne 2009; Tausiet, 2014; Machielsen 2020; Montesano 2020). Más allá de las trascendentes contribuciones previas (Cohn, 1975; Kieckhefer, 1976; Ginzburg, 1989) es posible señalar como fecha de nacimiento de este boom a la publicación de Thinking with Demons (1997) de Stuart Clark. Esta monografía, la más importante escrita hasta ahora sobre la temática, demostró la importancia central de la brujería y la demonología a lo largo de los siglos XV a XVIII en dimensiones centrales de la existencia humana como la religión, la política, la medicina y la ciencia. Efectivamente, a partir de los últimos años del siglo pasado, las bases intelectuales que llevaron a la persecución masiva de un crimen inexistente entre el Renacimiento y la llustración abandonaron de modo definitivo los márgenes de las principales corrientes de investigaciones históricas para ocupar un lugar de privilegio ${ }^{1}$. Tanto la existencia de

${ }^{1}$ Actualmente se considera que durante el periodo 1450-1750, entre cincuenta y sesenta mil seres humanos, la gran mayoría mujeres, fueron ejecutados en Europa por el delito de brujería, que incluía la comisión de todos o algunos de los siguientes actos imaginarios: pactos y mantener relaciones sexuales con demonios, utilizar magia nociva para dañar o destruir a otras personas y/o sus pertenencias, afectar el clima y otras calamidades semejantes por medios ocultos (Behringer, 2004, 149). Se calcula que el número aproximado de brujos condenados a muerte en Inglaterra, territorio del cual se ocupa el presente artículo, habría superado ligeramente el millar (Levack, 2006, p. 218). 
archivos judiciales seculares y eclesiásticos, como la enorme cantidad y variedad de tratados demonológicos que perduraron hasta nuestros días, han favorecido una proliferación de estudios regionales tal que si se observase un mapa europeo prácticamente no quedarían áreas sin cubrir (Levack, 2013a).

Inglaterra es un caso paradigmático de lo mencionado. Desde comienzos del siglo xx hasta la actualidad, los historiadores han prestado atención al fenómeno de la brujería y de las ideas a ella asociadas (Notestein, 1911; Macfarlane, 1970; Thomas, 1971; Sharpe, 1996; Gibson, 1999; Gaskill, 2005; Almond, 2012; Millar, 2017). El presente artículo pretende hacer un aporte en la materia. Se buscará analizar la relación entre demonología, posesión diabólica y discernimiento de espíritus, tres problemas no siempre vinculados por los académicos. Para ello se analizarán los tratados sobre brujería escritos por miembros de la elite cultural en Inglaterra entre 1580 y 1630, periodo que concentra la mayor cantidad de este tipo de publicaciones. Esta selección documental resulta apropiada porque en aquel reino el fenómeno de la posesión se consideró estrechamente vinculado con el accionar de los brujos. En estos escritos, los padecimientos de los posesos eran interpretados como el resultado de la invasión de demonios, o bien por causas naturales, como una enfermedad o una impostura. De esta manera, se propone como hipótesis que existía un explícito rechazo a la posibilidad de que los cuerpos poseídos fuesen anfitriones de la divinidad o de alguno de sus ángeles. Esta particular propuesta de discernimiento, alejada del paradigma vigente en la materia, era un subproducto del modo en que el discurso demonológico inglés entendía áreas más amplias de la teología como la Providencia y su relación con el colectivo humano, los milagros y los carismas, y la santidad, así como también del carácter inherentemente polémico de la tratadística contra la brujería del periodo. Los textos escogidos fueron redactados en su totalidad por teólogos o pastores protestantes, lo que permitirá estudiar los temas referidos sin perder de vista al marco teológico más amplio dentro del cual se inscribían.

\section{EL DISCERNIMIENTO DE ESPÍRITUS: PABLO, GERSON Y UN JESUITA INGLÉS}

«Pero a cada uno le es dada la manifestación del Espíritu para provecho. Porque a éste es dada por el Espíritu palabra de sabiduría; a otro, palabra de ciencia según el mismo Espíritu; a otro, fe por el mismo Espíritu; y a otro, dones de sanidades por el mismo Espíritu. A otro, el hacer milagros; a otro, profecía; a otro, discernimiento de espíritus; a otro, diversos géneros de lenguas; y a otro, interpretación de lenguas». En este pasaje bíblico, correspondiente a su primera carta a las comunidades cristianas de Corinto (1 Corintio 12,10), el apóstol Pablo de Tarso (c. 5-c. 67) menciona la variedad de dones que el Paráclito lega al grupo de seguidores de Cristo, 
no solo para su provecho interno, sino también para fortalecer la misión proselitista de difundir el mensaje divino a todo el orbe ${ }^{2}$. En tanto gratuitos y originados en la gracia divina, no eran la consecuencia de un determinado comportamiento o una retribución por un servicio prestado; tampoco se apoyaban en bases humanamente descifrables, sino en la inescrutable voluntad de Dios (Pitt-Rivers, 1993, p. 289). Dentro de la lista ensayada en 1 Corintios hay un carisma que resulta de especial interés para el presente artículo: el discernimiento de espíritus.

A pesar de que existieron diferentes interpretaciones para el mencionado don, Fabián Campagne señala que la que más consenso generó a lo largo del primer y del segundo milenio fue la que lo identificó con la capacidad para diferenciar la naturaleza de cualquier manifestación religiosa extraordinaria (profecías, apariciones, revelaciones, posesiones), es decir, con la facultad de poder distinguir si aquellas eran el resultado de una intervención divina, de ángeles, de demonios o si, en cambio, su origen se encontraba en la acción o la imaginación humana (2014, pp. 70-71). Aquellos portentos se caracterizaban por sus asombrosas similitudes exteriores, por lo que resultaba en extremo dificultoso reconocer cuál era su causalidad última. Este desafío era advertido en otro pasaje del epistolario paulino, «el mismo Satanás se disfraza como ángel de luz» (2 Corintios 11,14). De este modo, una aparición o arrobamiento diabólico podía disimularse o enmascararse como si fuera angélico o incluso divino ${ }^{3}$. La credulidad, pues, podía resultar enormemente peligrosa, motivo por el cual el Evangelio de Juan $(1,4,1)$ recomendaba «no creáis a todo espíritu, sino probad los espíritus si son de Dios». Los cristianos, entonces, tenían el deber de juzgar a los fenómenos espirituales extraordinarios antes de abrazarlos o rechazarlos.

Sin embargo, ninguno de los versículos citados en el párrafo anterior establece mecanismos o procedimientos para llevar a cabo la tarea probatoria (Caciola, 2003, p. 4). Esta indefinición escrituraria dio paso a extensas y complejas disputas, tanto acerca del significado del carisma paulino, como sobre su administración y control. En relación con esto último, se destacan las tensiones que se desarrollaron desde el tercer siglo después de Cristo entre las manifestaciones de la gracia con pretensiones de autonomía y la Iglesia, que luchaba por construir un control institucional sobre aquellas (Elliott, 2012, p. 197). Es así que recientemente se han identificado dos grandes etapas en la historia del discernimiento de espíritus en la tradición católica, una que se extiende entre el tránsito de la Antigüedad tardía a los albores el medievo (siglos III a VII) y otra que abarca desde la baja Edad Media hasta el cierre de la modernidad temprana (siglos XIV a XVIII). Ambos paréntesis cronológicos encierran poderosos desafíos al pretendido exclusivismo clerical: el monacato del desierto y

2 Todos los pasajes bíblicos que se utilizarán corresponden a la versión Reina-Valera de 1960.

${ }^{3}$ No extraña, entonces, que Pablo incluyera a la capacidad para ver detrás de ese velo entre las gracias obsequiadas por el tercer avatar de la Trinidad. 
el montañismo el primero; el misticismo y el joaquinismo el segundo (Campagne, 2014, pp. 71-72). Desde el punto de vista de la Iglesia, aquello que estaba en juego era su rol como instancia mediadora entre lo humano y lo divino. Resultaba realmente inconveniente la existencia de individuos o grupos para-institucionales que afirmaran poseer de manera no mediada la facultad de distinguir el origen de la amplia gama de manifestaciones espirituales en el mundo de la materia. Es por ello que, desde su punto de vista, el discernimiento de espíritus designaba la puesta en práctica de una desconfianza institucionalizada hacia aquellas exhibiciones carismáticas (Caciola, 2003, pp. 1-2). Lo que la Iglesia buscó lograr en ambos periodos, más allá de las especificidades de cada uno de ellos, fue garantizarse el control sobre el don del discernimiento de espíritus; en otras palabras, ser la única instancia válida capaz de reconocer el origen divino, diabólico o natural de las expresiones religiosas excepcionales. Así, solo serían aprobados como divinamente inspirados los visionarios, místicos o profetas que contaran con el beneplácito eclesiástico ${ }^{4}$. Por lo tanto, lejos de ser la gracia infusa y personal ideada por Pablo, la Iglesia convirtió al discernimiento en un dispositivo de control, homogenización y regulación para garantizar su rol central dentro del ecosistema cristiano.

Al comienzo de la Edad Moderna, durante la llamada segunda fase de la historia del discernimiento de espíritus, la posición de la Iglesia frente al tema se basaba esencialmente en la ensayada por el teólogo francés Jean Gerson (1363-1429) durante el siglo XV como respuesta a la creciente popularidad del misticismo afectivo, el cual se caracterizaba por una comunicación directa, emocional y personal del creyente con Cristo (Sluhovsky, 2007, pp. 175; Howells, 2012, p. 126). Esta novedad, además, se desarrollaba en medio del dramático Cisma de Occidente (1378-1417), que al duplicar la sede de la potestas terrena de la Iglesia erosionó por completo su criterio unitario de autoridad. Si en condiciones normales el Enemigo era capaz de mostrarse como un ángel de luz, en aquel contexto la facultad parecía potenciarse hasta el infinito. Es así que el Canciller de la Universidad de París, a pesar de la dificultad intrínseca propia del discernimiento espiritual, buscó normalizarlo con el doble objetivo de dotar a los creyentes de una herramienta para no caer en los engaños del Príncipe de las Tinieblas y de evitar que aquella fuese utilizada por fuera de la supervisión institucional. Gerson expresó sus ideas a lo largo de una trilogía de tratados publicados en un lapso de poco más de veinte años: De Distinctione Verarum Visionum a Falsis (1401), De Probatione Spirituum (1415) y De Examinatione Doctrinarum (1423). Esta propuesta, no obstante, no se inspiró en una postura anti carismática o en un intento por negar el entusiasmo religioso, ideas que ponían en peligro las revelaciones divinas pasadas y presentes (Copeland y Machielsen, 2013, p. 4; Campagne, 2014, p. 184). Tampoco buscó considerar a

${ }^{4}$ Los que no lo lograran pasarían a formar parte de colectivos menos afortunados: endemoniados, dementes o embusteros. 
la tarea del discernimiento como imposible. Lo que Gerson perseguía, por el contrario, era una vía media en la que los dones extraordinarios de los iluminados no fuesen probados/discernidos por ellos mismos, sino por los miembros de la alta cultura teologal. En su primer texto destacaba la humildad, la discreción y la paciencia como las marcas de una auténtica experiencia místico-visionaria, rasgos que se manifestaban en la obediencia del dotado a sus superiores (Caciola, 2003, p. 297). El sendero de la vía media lo continuó transitando en su segunda obra, donde escribe que el modo más efectivo, aunque nunca infalible, para poder discernir espíritus se encuentra en la combinación entre el conocimiento teológico hallado en las Escrituras y la posesión de ese carisma infundido por el Espíritu Santo. Por lo tanto, el evaluador de espíritus ideal era alguien que fuese a la vez un clérigo, un teólogo y un místico ${ }^{5}$. Nuevamente, el carisma quedaba resguardado dentro de los ortodoxos muros de le Iglesia (Sluhovsky, pp. 177-178). Finalmente, en 1423, profundiza la clericalización del don a partir del establecimiento de mecanismos de evaluación férreamente jerarquizados, en los que el candidato a iluminado podía confirmarse como tal únicamente si poseía la aprobación de la totalidad de los distintos escalones de la burocracia eclesiástica, los cuales en orden ascendente eran: los hombres instruidos en las escrituras, los doctores, los prelados, el papa y el Concilio universal. De esta manera, la versión definitiva del llamado «paradigma gersoniano» deslegitimaba por completo el autodiscenimiento, otorgaba una importancia secundaria al carisma paulino en relación a la sobrevaloración de la corporación teologal y sus múltiples capas de inspección y control, y sofocaba cualquier intento de legitimación para-institucional (Campagne, 2014, pp. 199-202) ${ }^{6}$. Más allá de que la aplicación práctica de estas ideas lejos estuvo de ser exitosa, Gerson se mantuvo como la autoridad religiosa en la materia dentro del catolicismo entre su muerte y el siglo XVIII (Caciola, 2012, pp. 35-36; Ossa Richardson, 2012, pp. 236).

El éxito de las ideas del teólogo francés puede comprobarse en el tratado The triall of the protestant priuate spirit, del jesuita inglés James Sharpe (1577-1630), publicado dos siglos después de su deceso. A lo largo de estas páginas, el clérigo

${ }^{5}$ Así, no es casualidad que De Probatione Spirituum incorporara una nota misógina ausente en De Distinctione, al señalar que las experiencias místicas femeninas siempre debían mirarse con sospecha (Elliott, 2012, p. 198). En este sentido, no conviene perder de vista que el documento se 1415 se redactó durante el Concilio de Constanza (1414-1418), donde se estaba debatiendo la posibilidad de reevaluar las experiencias de la mística escandinava Brígida de Suecia (c. 13031373), cuya canonización en 1391 aún no la libraba de sospechas en determinados círculos de la curia. Las visiones de la mística escandinava continuarían siendo objeto de discusión en el Concilio de Basilea (1431-1445). Sin embargo, su condición de Santa no pudo ser revertida por sus opositores, hasta el día de hoy se mantiene en los altares de la Iglesia Católica.

${ }^{6}$ Aun así, nunca dejó de ser probabilístico, no pertenecía al campo de lo infalible poder discernir una experiencia determinada, ni siquiera con el peso de la autoridad eclesiástica, como ocurría con el caso de Brígida. La iglesia no dejaba de estar compuesta por seres humanos imperfectos (Campagne, 2014, pp. 190-191). 
enumera las dificultades para bordar la tarea del discernimiento (existencia de distintos tipos de espíritus, la malicia y poder de Satán, la imperfección innata de los hombres), y si bien lo reconoce poco frecuente, reivindica la vigencia del don (Sharpe, 1630, pp. 79-103). Siguiendo el paradigma vigente, el selecto grupo de agraciados con este carisma estaba compuesto mayoritariamente por "los superiores", quienes debían dirigir a los otros en el camino de la virtud y la iluminación (Sharpe, 1630, p. 108). A su vez, el perfeccionamiento en la tarea de probar los espíritus provenía de la combinación de la inspiración divina, el conocimiento de las escrituras y la experiencia en la materia. Las profecías y las visiones, como cualquier carisma, no debían ni buscarse ni esperarse, tampoco ser gobernadas por inclinaciones personales (Sharpe, 1630, pp. 108-109). Por eso, la recomendación divina era que «ningún hombre sea instructor o director de su propia alma» para evitar equívocos o tentaciones (Sharpe, 1630, p. 111) ${ }^{7}$. Más importante que la adscripción de Sharpe a las ideas de Gerson resulta su ataque discursivo a las doctrinas protestantes imperantes en su tierra natal, las cuales consideraba que se alejaban de las fuentes de autoridad ortodoxas (las Escrituras, la tradición, la Iglesia, los concilios, la sede apostólica y la enseñanza de los Padres) y se apoyan en una libre interpretación personal de la revelación divina, a la que el autor denomina peyorativamente «private spirit» $(1630$, p. 2). Esta crítica la aborda desde la cuestión del discernimiento de espíritus. Por un lado, defendiendo la idea de que los dones espirituales y los milagros, aunque menos frecuentes que antes, siguen vigentes en su actualidad. Más relevante aún, sostiene que los protestantes no pueden juzgar correctamente a los espíritus porque rechazan todas las instancias de autoridad mencionadas más arriba. Debido a ello, no pueden saber «qué espíritu es bueno, cuál maligno, cuál es imaginario, cuál corporal, cuál es efecto de Dios, cuál del diablo» (Sharpe, 1630, p. 82). Es importante destacar que, para Sharpe, como para el resto de la ortodoxia católica, las apariciones de ángeles, las revelaciones divinas, las profecías, los milagros y las posesiones espirituales benignas eran actuales y posibles (1630, pp. 27 y 73-74). El protestantismo, en tanto desviación de la verdadera religión, rechazaba esa idea y creía ver «invenciones humanas o ilusiones diabólicas» detrás de lo que en verdad era un acto divinamente inspirado (Sharpe, 1630, p. 94). Si bien no los menciona, es factible que la descripción del discernimiento de espíritus realizada por Sharpe se inspirara críticamente en los tratados demonológicos publicados en Inglaterra, país del cual se exilió durante su juventud, pero al que supo regresar en calidad de misionero durante el periodo en el que aquel tipo de literatura conoció su auge (Muldoon, 2000, pp. 242-257; Méndez, 2020, pp. 544-545).

7 Todas las traducciones al castellano de fuentes, tanto primarias como secundarias, son de mi autoría. 


\section{DISCERNIR LAS POSESIONES EN LAS DEMONOLOGÍAS INGLESAS}

Como el discernimiento de espíritus, las posesiones forman parte del canon neotestamentario, tal como evidencian los diferentes relatos que destacan la capacidad exorcística de Cristo primero y de sus discípulos después (Mateo 12:22; Marcos 5:1-20; Lucas 4:33-36; Hechos 16:16-18, entre otros) ${ }^{8}$. Este fenómeno puede definirse como la invasión del cuerpo de un ser humano por parte de una entidad espiritual maligna que a partir de ese momento pasa a controlar sus operaciones físicas y mentales (Levack, 2013b, p. viii; Caciola, 2003, p. 41; Ferber, 2004, p. 3). Se la planteaba, entonces, como una afección preternatural que tenía lugar en el marco de la naturaleza; lo puramente espiritual habitaba lo netamente corporal (del Olmo, 2018, p. 77: Boddy, 1994, p. 407; Uszkalo, 2015, p. 19). Como cualquier enfermedad, poseía una serie de síntomas reconocibles, que en este caso se mantuvieron prácticamente sin modificaciones a través de dos milenios, y que fueron popularizadas por la cinematografía de las últimas cuatro décadas: fuerza física extraordinaria, entumecimiento de las extremidades, dolor, aversión a objetos sagrados, inanición, pérdida de la conciencia, convulsiones, flexibilidad muscular, glosolalia, clarividencia y, menos frecuente, la facultad de levitar (Levack, 2013b, pp. 6-15). Si la medicina formal o la folklórica no hallaban una solución natural a este cuadro clínico, el remedio que quedaba a disposición, al menos para la tradición católica, era el exorcismo, un rito por medio del cual se ordenaba la expulsión del huésped infernal (Young, 2016, pp. 1-27).

Más allá de los casos de posesiones registrados en la Antigüedad y el Medievo, los siglos XVI y XVII son considerados por los historiadores como la "edad de oro» de la posesión, lo que ha sido tradicionalmente asociado con la creencia contemporánea en el aumento de la influencia del demonio en el mundo material (Monter, 1976 , p. 60; Clark, 1997, pp. 389-422). Si bien las posesiones, la brujería y la demonología tienen historias independientes, no resulta aleatorio que su periodo de mayor influencia cultural coincida plenamente. Se entiende por demonología a la rama de la teología cristiana que se ocupa del estudio de las entidades diabólicas en todas sus dimensiones y expresiones, por lo que es tan antigua como el concepto mismo de Satán (Clark, 2006, p. 262). Sin embargo, desde el siglo XIII, y debido a las profundas transformaciones intelectuales ocurridas en Occidente, como la fundación de las universidades, el reingreso de la tradición clásica vía los contactos con el mundo árabe, así como el desarrollo del método escolástico, aquella antigua disciplina se convirtió en lo que los historiadores han llamado «ciencia del demonio", recientemente considerada por un especialista como la primera rama del conocimiento auténticamente «interdisciplinaria» debido a su capacidad para

${ }^{8}$ Cada uno de estos versículos refiere a posesiones diabólicas. La existencia de posesiones divinas recién comenzó a ser planteada en el siglo XII (Caciola, 2003, 24). 
incorporar elementos de otras áreas del saber, como la medicina, el derecho, la filosofía y la política (Machielsen, 2020, p. 10; Keck, 1998, pp. 72-78). Desde el siglo $\mathrm{xV}$, la demonología comenzó a estar inherentemente vinculada con la brujería diabólica, definida esencialmente como el establecimiento de un pacto entre un ser humano y el Príncipe de las Tinieblas o alguno de sus adláteres, lo que conllevaba una lógica abjuración de la fe cristiana. La brujería se convirtió así en la expresión más acabada del demonismo, y la mayor amenaza a la existencia misma del cristianismo, entre el medioevo tardío y el fin de la modernidad temprana, de allí que a los tratados escritos durante aquellos siglos para analizar las acciones de los brujos sean actualmente denominados como «demonologías». Teorizar sobre aquellos necesariamente implicaba hacerlo sobre la naturaleza, las características y las facultades de los espíritus impuros (Williams, 2013, p. 73). De esta manera, se considera como demonólogos a todos aquellos que redactaron tratados dedicados a analizar el problema de la brujería.

El presente artículo se ocupa de las demonologías publicadas por teólogos y ministros de la Iglesia de Inglaterra en el medio siglo que separa a 1580 de 1630, periodo atravesado por profundas tensiones económicas, políticas y, especialmente, religiosas, tanto entre católicos y protestantes, como entre las diferentes denominaciones que conformaban el campo reformado vernáculo. Entre los tratados escogidos se encuentran: A Discourse of the Subtill Practises of Devills by Witches and Sorcerers (1587) y A Dialogue Concerning Witches and Witchrafts (1593) de George Gifford (1548-1600); A Treatise Against Witchcraft (1590) de Henry Holland (1556-1603); A Discourse of the Damned Art of Witchcraft (1608) de William Perkins (1558-1602); A Treatise of Witchcraft (1616) de Alexander Roberts; The Mystery of Witchcraft (1617) de Thomas Cooper; y A Guide to Grand Jury Men (1627) de Richard Bernard (1568-1641). A partir del modo en que estos autores entienden el fenómeno de la posesión diabólica, se intentará demostrar la existencia de un modelo de discernimiento de espíritus alternativo al ofrecido por el catolicismo.

George Gifford, uno de los primeros demonólogos ingleses del periodo, aludió a la habilidad de Satán para ocupar cuerpos humanos. El Enemigo permanentemente «buscaba molestar y perturbar los cuerpos y las almas» $(1587$, p. 22). Era una de las ideas más arraigadas entre los teólogos reformados del periodo que la principal tarea del demonio era actuar como agente inductor de la tentación (Oldridge, 2010, pp. 105-106; Johnstone, 2006, pp. 1-2). Es adecuado pensar a las posesiones como la manifestación más evidente y acabada de dichas sugestiones y seducciones. Años después de las publicaciones de Gifford, el ministro Alexander Roberts consideraba que, así como Satán había ingresado metafóricamente en Judas para provocar la traición que da origen a la Pasión, también podía ingresar «realmente» a los organismos de las personas, como los Evangelios demostraban (Roberts, 1616, p. 29). Las posesiones devenían en uno de los medios privilegiados que el demonio tenía para poner a prueba a los electos y castigar a los condenados. Para esto último, 
por ejemplo, fingía ponerse al servicio de un brujo y ocupar los cuerpos de quien le fuera indicado, aunque en realidad podía hacerlo por propia voluntad, si contaba con el permiso de su Creador (Gifford, 1593, p. 84). La referencia a que la divinidad era la única instancia de control sobre los demonios era una idea compartida por el clérigo Thomas Cooper. En su tratado de 1617, advertía que Dios autorizaba a que el Caído y sus adláteres "penetraran las sustancias de las criaturas» y se alojaran en sus cuerpos (1617, p. 53). Tal como aclara Henry Holland, ni siquiera los más santos estaban exentos de ser atacados y ser «realmente poseídos» (1590, p. 58).

Respecto a las experiencias que atravesaban los endemoniados durante sus padecimientos, los ingleses no fueron especialmente originales. En su $A$ Guide to Gran Jury Men, el reconocido teólogo Richard Bernard enumeraba como signos de un verdadero poseso a la fuerza descontrolada, las autolesiones y la imposibilidad de ser sometido (1627, p. 64). Poco más de una década antes, el tratado de Roberts mencionaba también la ceguera, la sordera y un comportamiento desenfrenado (Roberts, 1616, pp. 19-20). El estereotipo se completa en The Mystery of Witchcraft, donde Cooper agrega a todo lo mencionado antes y después la capacidad de hablar lenguas extrañas (1617, p. 179).

Como mencionamos más arriba, si bien las posesiones divinas o angélicas no tenían base escrituraria como sí ocurría con las demoníacas, lo cierto es que desde el XII aquel fenómeno religioso extraordinario se había extendido notablemente en Europa de la mano de las diferentes oleadas de estallidos místicos. Desde la Edad Media en adelante, los pensadores cristianos identificaron un serio problema: los signos exteriores de las posesiones benignas y malignas eran virtualmente indistinguibles. Este desafío explica en parte la importancia que teólogos como Heinrich Von Langestein (1325-1397), Pierre D’Ailly (1351-1420) y, como vimos, Jean Gerson otorgaron a la cuestión del discernimiento. Si bien mencionamos que el paradigma diseñado por el último pervivió hasta los albores de la llustración, en medio de su periodo hegemónico se inició y desarrolló la Reforma protestante, la cual provocó profundas divisiones doctrinales y cultuales dentro de la otrora unida ecúmene cristiana occidental. Ello puede observarse en las demonologías inglesas.

Comencemos por el diagnóstico dado frente a síntomas y comportamientos como los descritos en los párrafos previos. Entre las distintas opciones que el discernimiento de espíritus otorgaba (intervención divina, angélica, diabólica o causas naturales), nuestros demonólogos solo consideraron como opciones explicativas las dos últimas. Siguiendo de cerca el mantra reformado de sola scriptura, los autores ingleses advertían a quienes considerasen como válidos en la actualidad los raptos divinos y las apariciones angélicas que "Satán se transformaba en un ángel de luz» (Gifford, 1587, p. 20; Holland, 1590, p. 42; Perkins, 1608, p. 19; Cooper, 1617, p. 187; Bernard, 1627, p. 162). De esta manera, la desconfianza era la postura inicial frente a cualquier candidato a iluminado o vector de la voluntad divina. Profundizando sobre esa idea, Gifford afirmaba en su Discourse que los espíritus impuros 
siempre buscaban imitar al Paráclito, así como también el demonio engañaba a las personas para que creyeran haber visto a ese avatar sagrado $(1587$, p. 9). Tres decenios después, Bernard apuntaba que Satán podía asumir la figura de un hombre santo para revelarle a los testigos secretos del pasado o el porvenir. Como puede verse, el sentido de la vista era víctima de una profunda ola de desconfianza debido a las facultades que el Adversario tenía en el campo del engaño y la mentira (Clark, 2007, pp. 123-236).

Tanto Gifford como Bernard eran especialmente severos con quienes se autoproclamaban huéspedes de una voluntad superior benigna. En A Dialogue Concerning Witches and Witchcrafts, el primero catalogaba como lo «más abominable para cualquier cristiano» la creencia en que realizaban cualquier clase de acción a través del "Espíritu Santo, un ángel o un espíritu bueno» (Gifford, 1593, p. 51). De manera semejante, el segundo destacaba que el que se presenta como un ángel piadoso es "la peor clase de demonio", ya que hacían creer a los hombres vanos que eran beneficiados directamente por Dios con la visita de su espíritu, lo que no era más que una ilusión. Más aún, indicaba que no había leído en ningún texto sagrado acerca de la posibilidad de que los ángeles ingresaran en los humanos (Bernard, 1627, pp. 83-85). Como fórmula para evitar caer en estas trampas, los demonólogos predicadores reivindicaban su rol en la sociedad. Perkins, por caso, exponía que conocer a Dios y su palabra era el mejor modo de «discernir las prácticas de Satán y sus instrumentos» $(1608$, p. 40). Por otra parte, su contemporáneo Henry Holland asociaba aquella capacidad con los dones presentes en «la doctrina del Evangelio» (1590, 10).

Sin embargo, aunque rechazasen las posesiones de tipo «benigno», la acción de los demonios no era la única explicación que auspiciaban. Aquello que se solía entender como prodigio religioso podía en verdad tener causas de tipo natural, por ejemplo, una enfermedad. Era frecuente en la literatura de la época la confusión o comparación de los síntomas de la posesión con los de otros padecimientos físicos en los que las intervenciones espirituales nada tenían que ver. Así, para Bernard, los profundos trances de los que los posesos parecían ser incapaces de despertar podían ser en realidad el resultado de un cuadro de catalepsia; así como el entumecimiento de alguna de las extremidades tranquilamente podía relacionarse con un ataque de apoplejía. Los espasmos y contorsiones musculares, en cambio, se asociaban con la "enfermedad de las caídas», el nombre de época para lo que la medicina moderna denomina epilepsia (Bernard, 1627, pp. 28-29). Este tipo de equívocos también podían observarse en relación a las visiones, apariciones u otras afecciones mentales propias del fenómeno posesorio. En este caso, la explicación natural que se ofrecía como alternativa era la melancolía. Heredado de la Antigüedad, el término se había vuelto inmensamente popular en la Europa renacentista. Inglaterra no fue la excepción, algo que puede observarse en la gran cantidad de obras dedicadas a la cuestión, entre las que destacan The Anatomy of Melancholy 
(1621) del erudito Robert Burton (1577-1640) (Schmidt, 2007, p. 4). Siguiendo las ideas del corpus hipocrático y de su desarrollo en la tradición galénica, se planteaba que el cuerpo humano basaba su correcto funcionamiento en el equilibrio entre los cuatro humores que lo componían: sangre, flema, bilis amarilla y bilis negra. El exceso de cualquiera de estos rompía el balance ideal. En nuestro caso, resulta clave el desequilibrio del último de los humores referidos, ya que, si la cantidad de bilis negra superaba el apropiado, la persona en cuestión adquiría las características propias de la melancolía (Bonzol, 2009, p. 121). Entre ellas se encuentran ansiedad, depresión, miedo, angustia, tristeza y fatiga crónica; también era considerada fuente de visiones y alucinaciones (Levack, 2013b, p. 117). Fueron estas últimas dos cuestiones a las que los demonólogos ingleses más atención prestaron. William Perkins explicó que las personas cuyos "cerebros estuviesen poseídos por la melancolía» se creían animales salvajes y copiaban sus costumbres. Esta condición alteraba por completo el entendimiento que tenían sobre ellos mismos y su entorno (Perkins, 1608 , pp. 13 y 43). Previamente, Gifford planteaba que la melancolía provocaba que los enfermos interiorizaran más profundamente cualquier estímulo o impresión sensorial, por lo que oían voces y veían figuras que no existían (1587, p. 29 y 62). No obstante, las explicaciones netamente naturalistas de la melancolía, como la hipocrática-galénica, convivían con la posibilidad de que el demonio afectará el ánimo de cualquier persona de manera interna o externa e indujera la enfermedad en ella o la potenciara en caso de que la inclinación humoral necesaria ya existiera (Schmidt, 2007, p. 132; Levack, 2013b, p. 118). Esto fue planteado por Gifford: "Satán engaña la mente ya dañada» para que los sentidos externos perciban lo que quiere $(1587$, p. 29). En este caso, como resulta propio del periodo estudiado, la naturaleza ordinaria y la preternaturaleza se entrelazaban ${ }^{9}$.

La otra explicación natural ponderada en los documentos escogidos no apelaba a la inocencia de los supuestos posesos sino a sus malas intenciones, algo que reflejaba la preocupación endémica en este periodo con la hipocresía y el fraude (Pearson, 2018, p. 102). Como indica Bernard, las posesiones podían «no tener lugar por enfermedades naturales o la intervención del demonio, sino por una falsificación de actos, impulsos, pasiones, perturbaciones, agitaciones, segregación de espuma por la boca... alteraciones de la voz, movimientos de los ojos» (1627, p. 45). Tal como recientemente ha señalado la historiadora Miriam Eliav-Feldon, durante la Edad Moderna la palabra «impostor» se asociaba principalmente con

9 De acuerdo a la teología cristiana, durante el periodo estudiado se asumía que la cosmología estaba dividida en tres órdenes o rangos: el sobrenatural, el preternatural y el natural. El primero refería a las acciones propias de la omnipotente deidad cristiana; el segundo a los actos de los espíritus puros, tanto benéficos (ángeles) como malignos (demonios), que, si bien formaban parte del orden natural, sus capacidades excedían a la de cualquier otra creatura; finalmente, el tercero aludía a los hechos de la naturaleza ordinaria siguiendo su curso de acción normal (Campagne, 2003, pp. 25-62). 
la religión, era un insulto dirigido a los rivales confesionales (2012, p. 67). Bernard, un clérigo identificado con la facción puritana dentro de la Iglesia de Inglaterra no dejó pasar la oportunidad para fustigar los supuestos exorcismos realizados por los misioneros jesuitas que desde el continente llegaban al reino británico para devolverlo a la senda de la ortodoxia romana. Así, en A Guide to Gran Jury Men denominó como "falsificaciones» a los posesos curados por Edmund Campion (1540-1581), quien junto a otros sacerdotes católicos se había "complotado" para impactar a los testigos e intentar convertirlos a su fe (Bernard, 1627, pp. 45-46). Antes que él, el médico y también demonólogo John Cotta (1575-1650) recordaba el caso de la falsa posesa francesa Martha Brossier (c. 1577-1600), que imitaba los sufrimientos de los endemoniados para beneficio de los papistas locales durante las Guerras de Religión (Cotta, 1625, p. 87). Más allá de las rivalidades intra-cristianas, Bernard atacó también al «falso profeta Mahoma», quien se aprovechaba de su epilepsia para hacer creer falsamente que sufría raptos divinos. Nuevamente, las delimitaciones se vuelven grises, ya que una enfermedad real no solo podía convivir con el accionar del demonio, sino también con la malicia de quienes la explotaban con fines proselitistas. Esta dificultad para distinguir entre una y otra no pasó desapercibido para Bernard, quien llamaba a recurrir a «médicos habilidosos» para discernir qué caso correspondía a cada una de las taxonomías posibles (1627, p. 41).

Estas ideas también pueden observarse en otros géneros teológicos o literarios desarrollados por individuos pertenecientes a sectores sociales semejantes y con similares inclinaciones ideológico religiosas que los demonólogos referidos. Entre el decenio de 1570 y el desenlace de la Revolución de mediados de la centuria siguiente, proliferaron en Inglaterra panfletos y libelos que daban cuenta de diferentes casos de posesión (Rosen, 1991, p. 213; Gibson, 1999, pp. 188-190). El avance de la cultura escrita durante aquel lapso de tiempo creó un público ávido de conocer noticias y sucesos extraños protagonizados no por personajes míticos de tierras lejanas, sino por individuos a los que pudieran conocer o con quienes se identificaran de algún modo. Una de esas historias fue la protagonizada por Helen Fairfax, la joven hija de un miembro de la gentry protestante de la localidad de Leeds. El texto, de hecho, fue escrito por Edward, el padre de la posesa, quien dio cuenta de los episodios donde su hija experimentó los síntomas clásicos de cualquier posesión, a los que pueden agregarse varios intentos de homicidio contra su persona o bien persuasiones para que se quitase la vida ella misma (Fairfax, 1621, pp. 36-39). Es el propio Edward el que asocia esta situación con un padecimiento "sobrenatural» al rechazar explicaciones alternativas y describir a su hija como "saludable, de complexión sanguínea y libre de melancolía» (1621, p. 32). Sin embargo, Helen proponía un autodiagnóstico. En uno de sus acostumbrados trances, la joven relató haber sido visitada por una presencia "resplandeciente de una gloria esplendorosa» que afirmaba ser un ángel enviado por Dios y la alentaba a cumplir tareas piadosas como orar y resistir las tentaciones diabólicas. El regresar de su travesía espiritual, 
estaba convencida de haber sido el receptáculo de la divinidad. No obstante, cuando Edward se hace eco de este episodio en su escrito, rápidamente desautoriza las palabras de su primogénita, al señalar que él y todos los presentes la persuadieron de que aquel episodio no era más que un engaño diabólico. Esto se confirmó en su siguiente desvanecimiento, cuando Helen enfrentó a la "gloriosa aparición» y le dijo que no creía que fuera un enviado divino: la criatura manifestó su verdadera naturaleza, abandonando su luminosidad para adquirir una figura perturbadora, con cuernos y deforme (Fairfax, 1621, p. 64). A la manera de los tratados demonológicos, el piadoso Edward Fairfax había convencido a su hija de que Satán se había transformado en ángel de luz, ocluyendo cualquier posibilidad de que su hija fuese una iluminada.

Una corrección similar ocurrió en otra conocida historia de posesión, la de Thomas Darling, "el niño de Burton», descrita en The Most Wonderfull and true story of a certain Witch named Alice Gooderige (1597). También proveniente de una familia puritana, el protagonista de trece años comenzó a sufrir los típicos síntomas de posesión en el año 1596. Sus padecimientos fueron conocidos por todos los habitantes de su pueblo, lo que lo convirtió en el foco de la atención local mientras duraron. Como Helen Fairfax, Thomas también perdía el conocimiento por largos periodos. Durante esos ataques su cuerpo era escenario de una compleja lucha espiritual en la que combatía por no aceptar las seducciones demoníacas. Según sus propias palabras, era capaz de oír voces y ver visiones celestiales, incluso de poder comunicarse directamente con Dios, quien «le abría los cielos». Sin embargo, Thomas también estaba bajo el control de una figura adulta que corregía y reinterpretaba lo que le ocurría. En este caso no era un pariente suyo, de hecho, su madre alentaba su comportamiento, sino el pastor de Burton, Master Eccarshall. El clérigo, lejos de aceptar lo que el pequeño relataba, le recomendó que «si el demonio le hablaba nuevamente, no debía contestarle porque era un mentiroso» (Almond, 2004, p. 169). La posesión divina ni siquiera era considerada como una opción a ponderar. Esta idea se completa con la intervención de John Darrell, el clérigo puritano que expulsaba demonios y entre 1599 y 1603 supo protagonizar un profuso y polémico debate con el por entonces obispo de Londres, Richard Bancroft, y su capellán, Samuel Harsnett, ambos reconocidos por su anti-puritanismo (Bhogal, 2013; Gibson, 2006; del Olmo, 2018, pp. 215-267). La «desposesión» de Darling, aunque no fue su primera, inauguró su lustro de mayor actividad en el área de la desposesión. Lo que resulta interesante es que su diagnóstico fue contundente desde el principio: «viéndolo en sus diversos ataques, le aseguró a él y a sus amigos que estaba poseído por un espíritu impuro» (Almond, 2004, p. 183). Años después, al defender su tarea frente a las autoridades eclesiásticas que lo acusaban de impostor, Darrell afirmaba que los casos que estaban bajo análisis no podían ser falsos debido a que los síntomas y comportamientos de los que fue testigo presencial no podían ser el resultado de «una causa natural, por lo que debían ser sobrenaturales, es decir, la 
posesión de un espíritu maligno» (Darrell, 1599, pp. 15-16). Un año después, era aún más taxativo: "¿y que otra cosa podrían ser si no eran espíritus malvados los que estuvieran dentro de ellos?... excepto que seamos tan vulgares de imaginar que Dios lo produjo directamente... o a través de un ángel elegido, cuando ninguna de las dos puede ser posible» (Darrell, 1600, pp. 1-2). Aquí también se observa una adhesión al paradigma sobre las invasiones espirituales que por entonces estaban construyendo los demonólogos ingleses y que estaba totalmente alejado del sostenido por el jesuita Sharpe: las posesiones divinas no formaban parte del catálogo de discernimiento.

\section{EL MARCO TEOLÓGICO}

Esta propuesta de discernimiento no resultaba caprichosa o aleatoria; más bien se manifestaba como una premisa lógica dentro de los postulados teológicos generales mantenidos por los demonólogos. Entre ellos, el más importante era el modo en que se planteaba la relación entre la deidad y el colectivo humano. En el caso de los protestantes ingleses, especialmente los puritanos como los demonólogos considerados, esto se vincula con el concepto de Providencia. Formaba parte de la ortodoxia del pensamiento religioso de aquel grupo la idea de que Dios no era un espectador inactivo de su creación. Por el contrario, su presencia e interés era, de una manera u otra, permanente. En el libro más exhaustivo sobre este tema escrito hasta la fecha, Alexandra Walsham apunta que la mayoría de los miembros de la elite cultural del periodo diferenciaban entre la Providencia general y la particular. La primera refería al programa que comprendía la evolución del macrocosmos de acuerdo a las leyes establecidas al momento de la génesis; mientras que la segunda frecuentemente designaba a la vigilancia divina a nivel microscópico, al instinto secreto que guiaba de manera sutil pero necesaria a todas las criaturas de acuerdo al plan predestinado para ellas en el episodio iniciático. También se incluían entre las providencias especiales o particulares ciertos acontecimientos fuera de la normalidad, ya sea para sostener el orden moral o para premiar y advertir a los humanos. Esta idea podría parecer contradictoria, tanto al lector moderno como a los hombres y mujeres de aquel tiempo; sin embargo, las providencias especiales no eran improvisaciones sino eventos que encajaban perfectamente en el programa establecido y fijado antes de que el Tiempo comenzara (Walsham, 2003a, pp. 12-13).

Esto se vincula con varias ideas del teólogo francés Juan Calvino (1509-1564), especialmente el modo en que entendía los milagros. De acuerdo con el autor de Institution de la Religion Chrétienne, los milagros existieron solo temporalmente durante el cristianismo primitivo con el objetivo de sostener y fortalecer la nueva religión en su etapa embrionaria (Calvino, 1888, pp. 666-667). Los poderes que usufructuaron los apóstoles y otras figuras del culto cristiano no solo no les pertenecían 
a sus personas, sino que creer que eran una característica universal y perenne de la santidad constituía un grave error (Eire, 2003, pp. 222-223). Sugerir que esos portentos aún tenían lugar daba cuenta de la credulidad humana y de los espejismos diabólicos. Sin embargo, el francés no se mostró tan tajante sobre el fin de los milagros como lo harían los calvinistas posteriores; de hecho, la naturaleza entera encerraba en sí misma innumerables milagros (Calvino, 1888, pp. 24-25). En esta cosmología donde el movimiento de los cielos y la misma existencia humana eran hechos asombrosos, lo supernatural no existía como una categoría separada, estaba subsumido en la naturaleza puesto que todos los eventos eran parte del plan divino (Sluhovsky, 1991, p. 10). No negaba, entonces, la continuidad de los milagros, lo que rechazaba era la acepción más técnica del término, aquella que la asociaba a hechos o acontecimientos puntuales que quebraban el orden natural. Si se los concebía de ese modo, efectivamente eran parte del pasado, mientras que, si se los interpretaba según el modo más general que él sugería, eran actuales y habrían de continuar hasta el fin de los tiempos. De esta manera, lo que ocurrió en la obra de Calvino fue que su doctrina de los milagros convergió con la idea de la Providencia, tanto la general como la particular. Aquellos que formaban parte de la verdadera Iglesia podían ver la mano de Dios en eventos de su vida cotidiana: nacimientos, cosechas abundantes, el curso de las aguas, los movimientos de los cuerpos celestes, la prosperidad económica personal y en la confianza de saberse parte de aquellos escogidos para disfrutar de la vida eterna ${ }^{10}$. Los santos no eran ya realizadores de prodigios asombrosos, sino la totalidad de la comunidad de seguidores predestinados a recibir la gracia (Sluhovsky, 1991, p. 10). El milagro no consistía, pues, en la mutación violenta o inesperada del mundo material, sino en una efusión de fe interior que permitiera tanto comprender a la creación en toda su dimensión, como el avance de la verdadera Iglesia (Eire, 2003, p. 224).

Este entramado de conceptos permea los tratados demonológicos ingleses. Respecto del ordenamiento y control divino sobre su Creación, más arriba se mencionó que los demonios solo podían actuar en el mundo material si la divinidad antes lo autorizaba. Por ello, Cooper consideraba que era «robarle la gloria a Dios» sostener que un brujo podía comandar a una entidad infernal, ya que aquel era el único que podía manipular a esas fuerzas de acuerdo a su Providencia (1617, p. 85). De la misma manera, se cometía una falta igualmente severa cuando las personas víctimas de un embrujo buscaban vengarse en lugar de pensar que fue "la mano del Señor» la que permitió que ese hecho ocurriera y que, por lo tanto, habría de redundar en "algo positivo para sus elegidos» (Perkins, 1608, p. 50). Saliendo de

10 También deben incluirse experiencias dañosas como enfermedades, inundaciones, incendios, batallas perdidas, nacimientos monstruosos o abundancia de brujos, las cuales debían ser interpretadas como milagrosas advertencias del Creador para que los humanos enmendaran su proceder pecaminoso (Walsham, 2005, p. 289). 
lo estrictamente vinculado con el accionar de los brujos, Gifford señala que el Ser Increado utilizaba a los espíritus impuros de acuerdo a su plan para «mostrarle su furia a los malignos y probar a sus elegidos» (1587, pp. 23-24). Según Bernard, los demonios podían producir incontables actos nefastos, pero nada de ello ocurría con autonomía de la «mano de la Providencia» (1627, pp. 18-19). En relación a la dicotomía existente entre aquellos que formaban parte del rebaño divino y los condenados eternamente, Holland buscó evitar cualquier clase de equivoco. De acuerdo con lo analizado por Walsham, "la Providencia general» estaba presente en todas las obras. La Providencia especial de amor y piedad, en cambio, estaba reservada a «sus santos» (Holland, 1590, p. 54). En este sentido, siguiendo el postulado calvinista de la predestinación, el ya aludido Cooper remarcaba que los que serían salvados al final de los tiempos habían sido escogidos por la «Providencia del Todopoderoso» antes que las bases del mundo hubiesen sido establecidas» $(1617$, p. 3).

En lo que respecta a los milagros, la postura cesacionista de los autores ingleses es tan evidente como intransigente. La base de su idea es que los milagros pertenecen al pasado: entendidos como efusiones prodigiosas y completamente disruptivas, aquellos no formaban parte de su contemporaneidad. Daniel, uno de los personajes del Dialogue de Gifford, explica que los apóstoles y otros durante la etapa de la Iglesia Primitiva recibieron extraordinarios poderes por intercesión del Espíritu Santo, pero que no por ello debía «establecerse un patrón» hasta el presente $(1593$, p. 83). Perkins también destaca el carácter excepcional del periodo fundacional de la comunidad de seguidores de Cristo, aquel de la «infancia del Evangelio» en el cual abundaban los dones espirituales maravillosos (1608, p. 49). Esta idea general Bernard la aplica a un caso particular. De acuerdo con su tratado, cualquier remedio utilizado para devolver la salud puede tener o un origen natural o uno de tipo extraordinario. Dentro de este tipo incluye a aquellos que provienen de Dios y a los que propone el diablo. En su propio presente, el teólogo solo considera posibles a los últimos, debido a que los de la deidad siempre son milagrosos, "pero ese tipo de trabajos ha cesado hace largo tiempo» (Bernard, 1627, pp. 139140). Los milagros solo son considerados propios de la era apostólica porque fueron necesarios para confirmar la fe cristiana en sus comienzos. Defender su existencia en el presente sembraba dudas tanto acerca de la labor de los apóstoles como sobre la eficacia del Evangelio, ya que parecía que su mensaje solo podía ser creído gracias a los portentos que quebraran el orden natural (Cooper, 1617, pp. 299-300). Los milagros, sencillamente, ya no eran necesarios; los protestantes sabían que "ya no quedaban esa clase de dones en la iglesia» (Perkins, 1608, p. 4 y 50).

La idea del fin de los milagros desarrollada hasta aquí se conecta con el problema de las posesiones divinas a partir de dos cuestiones asociadas a ella: la profecía y las visiones. Como se mencionó más arriba, la posibilidad de predecir eventos futuros y de tener acceso a diferentes imágenes de los avatares divinos y/o de algún miembro del panteón cristiano eran dos de las habilidades que se les solía adjudicar 
a los iluminados. En efecto, ambas solían presentarse de manera conjunta, las capacidades proféticas solían revelarse en los mismos trances en los que tenían lugar los contactos directos con Dios. En relación con los oráculos, Anthony Ossa Richardson destaca la inherente desconfianza manifestada hacia ellos por parte de la religión de los seguidores de Cristo. Sin embargo, como ocurrió con diversos elementos provenientes de las culturas religiosas previas, la estrategia no fue la de un abierto rechazo, sino la de una apropiación con alteraciones. El oráculo de Delfos, el más importante de la Antigüedad mediterránea, servía como autenticación de las profecías del Dios cristiano. El hiato que las separaba se explicaba de manera sencilla: la inspiración del primero era Satán, mientras que las segundas provenían del Paráclito. La malicia del Adversario les daba sentido a todas las historias oraculares del llamado paganismo, así como estas servían de evidencia para la teoría de la adivinación diabólica (Ossa-Richardson, 2013, pp. 61 y 69). La referencia crítica a Delfos llegó incluso a las demonologías inglesas. Perkins contrapuso el Tabernáculo donde la divinidad se comunicaba con Moisés al oráculo délfico o el de Dodona, donde el Príncipe de las Tinieblas se manifestaba a los «supersticiosos paganos» $(1608$, p. 3). Holland también colaboró en la largamente establecida tradición de demonizar la cultura clásica: las pitonisas de Filipo y Éfeso eran instrumentos satánicos (1590, p. 21). En ocasiones, incluso, algunos episodios del Antiguo Testamento establecían la asociación entre los adivinos y el Enemigo. El encuentro de Saúl con la bruja de Endor (1 Samuel 28, 8-13) no había propiciado la manifestación del alma de Samuel profetizando el futuro, sino la de un espíritu demoníaco que tomó su forma para engañar al primero, ya que "las almas de los muertos no regresaban a la tierra» para reunirse con los vivos (Holland, 1590, p. 33). Esta idea se basaba en el rechazo a la teoría católica del purgatorio. Al negar la existencia de este espacio intermedio entre el Paraíso y el infierno, los protestantes creían imposible el regreso al mundo material de las almas humanas luego de su muerte para buscar expiar los pecados cometidos en vida (Clark, 2007, p. 207).

Más allá de los pasajes aludidos, quien más extensamente se ocupó de estas cuestiones fue Cooper. Además de calificar como «profetas de Satán» a las viejas sibilas, también llevó su crítica al presente, donde en diversas partes de Europa florecían relatos de místicos o inspirados (Cooper, 1617, p. 216). En muchos casos, quienes se autodefinían de ese modo afirmaban haber visto a la divinidad en sus sueños o trances, tal como vimos que ocurrió con Helen Fairfax o Thomas Darling. El clérigo mostró especial interés en aclarar qué ocurría realmente en esas situaciones. Para ello clasifico a los sueños en tres categorías: divinos, naturales y diabólicos. En los primeros, el Creador infundía imágenes o sensaciones de manera directa; en los segundos, aquellas tenían un origen fisiológico producto de la falta de balance humoral; en los últimos, la causa eficiente era el accionar de Satán en el cerebro de las personas (Cooper, 1617, pp. 145-146). En relación con los primeros, podían ser reconocidos si allí se producían revelaciones edificantes para la 
adoración del verdadero Dios o que redundaran en el bien de la Iglesia, entendida como la comunidad de creyentes. Además, los trances divinos suspenden momentáneamente las facultades del alma y el cuerpo, sin que pierdan su perfección y correcto funcionamiento; mientras que los inducidos por el Caído llevaban a la locura, el frenesí y nunca lograban separar efectivamente el espíritu humano de su envase material (Cooper, 1617, pp. 2-3 y 156-157). Sin embargo, este consejo para discernir entre los tres tipos de sueños solo resultaba útil en el pasado. Para los eventos del presente, el modo por el que se podía distinguir el primer tipo de sueños del tercero era más sencillo. En la contemporaneidad de Cooper, «el Evangelio había revelado la voluntad de Dios de manera suficiente», por lo que no era necesario apoyarse en ensoñaciones o trances como los mencionados. De esta manera, «lo que antes era ordinario y estaba de acuerdo con la Ley» ahora era una «ilusión satánica» (Cooper, 1617, pp. 148-149). El divorcio del cuerpo y el alma relatado por los supuestos iluminados era considerado por el clérigo como un milagro y por lo tanto únicamente al alcance de Dios. Sin embargo, como ya hemos visto, estos hechos extraordinarios vividos en el pasado, por ejemplo, por los apóstoles, había cesado. Perkins también compartía estas ideas. Al preguntarse cómo era posible «discernir entre las revelaciones diabólicas y el verdadero don de la profecía», llamaba a recordar la simiesca costumbre de Satán de imitar a Dios. Así como «en tiempos pasados» el Creador había elevado a los profetas para la construcción de su Iglesia, Satán inspira en el presente a sus ministros para erigir su reino (Perkins, 1608, p. 31). En conclusión: "debe recordarse que, aunque haya distintos tipos de sueños, aquellos que son de Dios solo fueron ordinarios en el Antiguo Testamento, cesaron en el Nuevo y ya no tienen lugar», de manera que solo pueden ser producto de la naturaleza, del demonio, o de una combinación entre ambos (Perkins, 1608, p. 27).

A partir de lo escrito, puede reconocerse en los documentos la transformación de la idea de santidad ya advertido por Carlos Eire en la teología calvinista. Perkins, por caso, llamaba a desconfiar y sospechar de aquellas doctrinas que se basaban en maravillas y portentos. La Iglesia, es decir, la comunidad de los santos escogidos para salvarse, no cumplía su rol a través de este tipo de acontecimientos, como había ocurrido en sus inicios (Perkins, 1608, p. 15). De esta manera, el discernimiento no podía entenderse como el carisma paulino. Antes que infundido por el Espíritu Santo, para Cooper provenía de la verdadera Iglesia, aquella que se diferenciaba de la sinagoga satánica por no estar basada en milagros actuales. El respeto por la doctrina, la pertenencia a la comunidad, la oración y la participación en el sacramento de la Cena eran los instrumentos para reconocer y alejarse de la falsa fe (Cooper, 1617, p. 355). Así, cuando Holland habla del «don del discernimiento» tampoco refiere a una expresión carismática, sino a la claridad que Dios les otorga a sus santos a través de su Palabra y de la alianza con su Espíritu. Este último no era ya una prerrogativa personal otorgada por la gracia a determinados individuos, sino una bendición general a todos los elegidos (Holland, 1590, p. 10 y 35). De esta manera, 
los santos del presente lo eran por su conocimiento y respeto hacia la Palabra, por llevar una vida inspirada en las enseñanzas de Cristo y por la fe, no por sus cualidades milagrosas, proféticas o místicas.

Antes de pasar a las conclusiones, resta ocuparnos de las formas mediadas de intervención divina en el mundo de la materia, ya que además de hacerlo de manera directa, podía recurrir a sus huestes angélicas. En un estudio reciente, Alexandra Walsham y Peter Marshall consideraron a la Reforma como un quiebre en el modo en que el cristianismo occidental entendía a aquellos seres. En el afán por suprimir cualquier instancia mediadora entre los hombres y la divinidad que no fuera Cristo, tuvo lugar una campaña para evitar la devoción y el culto a los ángeles, que en tanto criaturas no merecían ningún tipo de honor. Además, la combinación del principio de sola scriptura con la postura cesacionista en relación a los milagros dejaba poco espacio para nuevas intervenciones angélicas. Se consideraba que estas entidades espirituales ejercían una protección permanente de tipo general sobre los humanos, no personal o individual como marcaba la tradición católica de los ángeles guardianes (Gillespie, 2006, p. 221). Tampoco esperaban los reformados que se comunicaran con ellos directamente o aparecieran visualmente (Walsham y Marshall, 2006, pp. 17-18; Sangha, 2012, p. 274) ${ }^{11}$. Esto puede comprobarse en The Mystery of Witchcraft. Allí, Cooper recuerda que los ángeles protegían y reconfortaban a las personas $(1617$, p. 285). El enunciado no es especialmente generoso con su contenido; lo que se observa es que la existencia de los espíritus angélicos no es rechazada, aunque no plantea que se manifiesten visiblemente o que interactúen con los humanos de modo directo.

Resulta un desafío insuperable intentar hallar en las demonologías fragmentos que avalen esas posibilidades. De hecho, es posible encontrar varios que las niegan abiertamente. Volvemos entonces a la cuestión de las posesiones angélicas. Anteriormente se mencionó que Bernard basaba su escepticismo en que las Escrituras no relataban nada semejante, por lo que creer en ello resultaba temerario. Además de este argumento irrebatible desde la cosmovisión protestante, el teólogo mantiene su posición negativa apelando a la lógica. La posibilidad de que un ángel se alojara en un cuerpo humano resultaba incongruente, tanto en el caso de los piadosos como en los condenados. En los primeros, la presencia invisible del Espíritu Santo volvía innecesaria la visita de un mensajero celestial. En los segundos, en cambio, aquello era imposible debido a «su vida disoluta, irreformable, sensual y vacía de la gracia». Así, sin importar su condición moral, aquellos que creían escuchar en su interior la voz de un ángel y un demonio al mismo tiempo, en verdad solo escuchaban a este último duplicando su tarea (Bernard, 1627, pp. 83-85). Por

${ }^{11}$ Consecuente con lo apuntado más arriba, si algo semejante aparecía frente a los ojos humanos era el producto de la intervención de un demonio o una fantasía humana (Clark, 2007, p. 208). 
último, Perkins menciona el caso de José, quien recibió la noticia de la Inmaculada Concepción por medio de un ángel, y el de los profetas que revelaban el porvenir gracias a sueños donde seres semejantes intervenían. Lejos de poneros en duda, el teólogo puritano señala que ese tipo de adivinaciones «no debían ser censuradas como ilegales» debido a que era una de las formas en las que "en el pasado» Dios se había comunicado con los suyos (Perkins, 1608, p. 25) En el presente, no obstante, eso no era necesario. Siguiendo la idea de que los posesos eran intérpretes de un drama colectivo y que se comportaban de acuerdo a lo que se esperaba de ellos socialmente (Levack, 2013b, pp. viii-ix; Caciola, 2003, p. 83), en este caso, el guion que se les proponía desde los tratados sobre brujería no incluía entre sus líneas la posibilidad la inspiración divina. No porque fuese imposible de llevar a cabo para una deidad omnipotente, sino porque era culturalmente inaceptable para los demonólogos en aquel contexto.

Ahora resulta posible comprender más adecuadamente los motivos del jesuita Sharpe para publicar su tratado en 1630, poco después de finalizado el recorte cronológico que encierra las demonologías escogidas. Cuesta creer que desde su punto de vista el «private spirit» que tan duramente criticaba no estaba presente en el modelo de discernimiento desarrollado por los demonólogos ingleses ${ }^{12}$. Esta interpretación protestante de la teología cristiana, que para Sharpe se alejaba de la ortodoxia y traicionaba la tradición, terminaba desterrando por completo la posibilidad de que las manifestaciones más espectaculares de la Providencia existieran en el presente. Mientras que la suya, donde los milagros, los carismas y las intervenciones de los ángeles eran actuales sostenían el modelo tripartito de posibilidades frente a los portentos espirituales. De esta manera, las diferencias entre el modelo de Sharpe, basado en el denominado "paradigma gersoniano", y el de los demonólogos ingleses excedía largamente la cuestión del discernimiento de espíritus. Diferencias teológicas generales más profundas provocaban un reordenamiento de la relación del triple umbral de posibilidades cristiano, que redundaba en una drástica reducción de los portentos extraordinarios de origen divino en el mundo material, los cuales solo podían ser producto de seres preternaturales maléficos o de la naturaleza.

\section{CONCLUSIONES}

En publicaciones recientes se han advertido distintos motivos para el surgimiento de la literatura demonológica docta en Inglaterra durante la década de

12 Resulta valido pensar si no podría incorporarse a la reforma protestante a la lista de desafíos al exclusivismo de la Iglesia católica entre aquellos sucedidos durante la segunda etapa del discernimiento de espíritus y mencionados al comienzo de este artículo. 
1580, entre los que destacan la voluntad de rebatir los postulados escépticos de Reginald Scot en su The Discoverie of Witchcraft (1584), la definición del crimen de brujería, el combate contra la superstición, así como también la adaptación de las ideas populares acerca del demonio y los brujos a la ortodoxia reformada (Méndez, 2020). De esta breve enumeración se desprende el carácter inherentemente polémico del discurso demonológico, algo que lejos está de ser exclusivo del caso inglés. Más allá de su relación con los temas centrales de las demonologías, y de la teología en general, como hemos visto, la importancia que los autores hasta aquí estudiados otorgaron al discernimiento de espíritus también respondería a una necesidad polémica específica. Durante el mismo decenio en que empiezan a aparecer los primeros tratados de este tipo, las misiones católicas a Inglaterra, especialmente las de los jesuitas, se volvieron más frecuentes y agresivas en su campaña para recuperar el terreno perdido frente a los protestantes. Una de las herramientas de proselitismo más efectivas que desplegaron fue el recurso a la realización de milagros, las visiones y los exorcismos, inspirados en la estrategia postridentina de reforzar a la Iglesia Católica como reserva de poder numinoso (De Waardt, 2009, p. 346; Walsham, 2003b, pp. 781-786). La intención de fondo era multiplicar el número de prodigios realizados por la casta sacerdotal católica y contraponerlo con la postura del cese de los milagros sostenida por las corrientes teológicas principales de aquel reino. De esta manera, se buscaba demostrar que el cesacionismo no era un principio ideológico, sino el resultado de que los reformados no eran receptores de la gracia como sí lo eran los sacerdotes romanos. Entre las décadas de 1580 y 1620 se han registrado campañas de exorcistas católicos itinerantes, sobre todo en los condados del norte, donde la «vieja religión» continuaba fuertemente arraigada. Muchos de los posesos también manifestaban habilidades proféticas y, más importante aún, estar poseídos no solo por demonios sino también por los espíritus de la Virgen María, Juan Bautista o el Arcángel Miguel (Walsham, 2003b, p. 805) ${ }^{13}$. Este lapso de cuarenta años coincide prácticamente a la perfección con aquel en que se publicaron las demonologías escogidas. El modelo de discernimiento de los demonólogos buscaba desautorizar las principales herramientas proselitistas de sus enemigos confesionales ${ }^{14}$. No quiere decir esto que sus ideas sobre el tema fuesen

${ }^{13}$ Algo que se complementaba con las poderosas experiencias místicas que los santos contrarreformados como Teresa de Ávila (1515-1582), Juan de la Cruz (1542-1591), Felipe Neri (1515-1595) o Francisco Javier (1506-1552) habían atravesado en vida y habían servido como evidencia para elevarlos a los altares. Sus historias llegaban de contrabando a Inglaterra, junto con medallas de sus imágenes (van Dijkhuizen, 2009, p. 194). Reliquias y raptos místicos eran, justamente, dos áreas en las que el protestantismo poco tenía para ofrecer en su competencia con el frondoso arsenal cultual católico (Thomas, 1971, p. 479).

14 Tampoco resulta casual que en medio de la "epidemia» de exorcismos católicos en Inglaterra surgiera la contrafigura de John Darrell, un especialista puritano en la expulsión de demonios. Este buscaba diferenciarse de los misioneros afirmando que sus «desposesiones» no 
únicamente el reflejo de la disputa con los católicos. Como vimos, sus posturas tenían bases teológicas evidentes. Lo que se sostiene es que hubo una combinación entre teología y polémica o, en otras palabras, un uso polémico de su interpretación de los axiomas de la doctrina cristiana que avalaban.

La publicación de las demonologías también se produjo en un contexto histórico en el que tanto católicos como reformados desplegaron una clasificación dual para la amplia gama de seres o entidades moralmente neutras que poblaban el universo cultural de la Europa preindustrial. Así, elfos, duendes, ninfas, faunos, hadas y cualquier espíritu doméstico fueron asimilados a la estructura binaria de ángeles o demonios. Toda criatura espiritual debía pertenecer a una u otra categoría, ya no había lugar para clasificaciones intermedias. Euan Cameron apuntó que más que discernimiento, este proceso constituyó una «reinterpretación obligada de experiencias previamente entendidas de acuerdo con otro sistema de creencias» (Cameron, 2006, 18). Es probable que ello, en realidad, sea una característica intrínseca del dispositivo teológico «discernimiento de espíritus» a lo largo de toda la historia cristiana, al menos desde el punto de vista de las instituciones religiosas y su afán de control. De hecho, si hay algo que el modelo de discernimiento de los demonólogos ingleses tuvo en común con el de Gerson fue que ambos, aún con diferencias ontológicas, buscaron garantizar el control de los eclesiásticos y expertos en teología sobre los juicios y evaluaciones de experiencias espirituales y religiosas fuera de lo común ${ }^{15}$.

Para finalizar, es necesario destacar que las ideas sostenidas por los autores trabajados no pueden ser generalizadas al conjunto del protestantismo inglés ni tampoco a todo el periodo de la modernidad temprana. Páginas más arriba demostramos como Helen Fairfax, Thomas Darling y su madre estaban convencidos de que era posible que la divinidad o una presencia angélica se alojasen en un cuerpo humano. Eran los miembros de la corporación teologal los que censuraban la idea como parte de una campaña más amplia para difundir la ortodoxia reformada. Sin embargo, en otro contexto histórico, esta situación podía ser diferente. En el marco

se basaban en el hecho de tener un poder o carisma personal para desalojar espíritus impuros, sino en un ruego a la divinidad a partir de la realización de ayunos y rezos (del Olmo, 2018, p. 248; Bhogal, 2013, p. 6; Sands, 2004, pp. 113-114). Está aún por escribirse una investigación que se plantee si existió una relación entre la controversia de Darrell y las autoridades de la Iglesia de Inglaterra y el pensamiento de los demonólogos ingleses en relación a las posesiones y las desposesiones.

${ }^{15}$ Esta defensa de la institución eclesiástica también se ve en la crítica de los demonólogos a los sanadores carismáticos (Méndez, 2020, pp. 477-525). Sin embargo, este grupo perteneciente al ala puritana del protestantismo vernáculo también supo distanciarse de decisiones y posturas sostenidas por la cúspide de la burocracia religiosa, por lo que la relación entre los primeros y la estructura de la que formaban parte es más compleja de lo que a primera vista puede suponerse (Méndez, 2020, pp. 561-592). 
de la Revolución de mediados de siglo XVII, donde el puritanismo luchaba por hacerse con el control del reino y de la Iglesia, ambas en manos de individuos y grupos más conservadores en materia religiosa, la respuesta fue completamente diferente, como muestra el caso de Margaret Muschamp relatado en el panfleto Wonderful Newes from the north (1650). Allí, se describe como la niña de once años perteneciente a una familia puritana de Northumberland manifestó evidentes síntomas de una posesión, entre los cuales el último fue un profundo trance. Al despertar, le pidió a su madre que no se lamentara, puesto que había tenido una visión feliz y que «el Señor había amado su pobre alma, soplado las trompetas divinas en sus oídos y enviado dos ángeles» (Almond, 2004, p. 364). En ocasiones posteriores también refirió a otras visitas angélicas, descritas como «las criaturas más dulces sobre las que haya posado su mirada» (Almond, 2004, p. 375). Hasta aquí la situación no presentaría novedades en relación con lo vivido por Helen o Thomas años antes. La diferencia surge a partir de la reacción del clérigo interviniente. De acuerdo a lo registrado, el ministro creyó y alentó el comportamiento de Margaret, bendiciendo a Dios «por mostrarle tal piedad» a una niña (Almond, 2004, p. 364). Esta reacción se explica esencialmente por el disruptivo contexto en el que se produjo. Tal como señala Diane Purkiss, la representación de la niña como una mártir atormentada equivalía a atestiguar como cierta su fe y toda la causa de los puritanos. Era la oportunidad perfecta para demostrar la persecución liderada por la Iglesia de Inglaterra contra aquel grupo (Purkiss, 1998, pp. 238-239). En este periodo, el puritanismo se presentaba como una opción que rivalizaba con la institución eclesiástica, por eso apelar a las posesiones divinas resultaba apropiado para diferenciarse de sus rivales $^{16}$. La crisis interna provocó una proliferación de visionarios, profetas y otros iluminados, cuya existencia fue seguida con interés tanto por los sectores populares como por la elite cultural (Oldridge, 2010, p. 133; Scott, 2006, p. 201; Mack, 1992, p. 121). En cambio, en el periodo comprendido en el análisis de este artículo, esa ruptura dentro de la Iglesia no se había producido; existían tensiones, pero no un quiebre en el contexto de un enfrentamiento bélico intestino. Entre 1580 y 1630, la amenaza eran los prodigios católicos, dentro y fuera de Inglaterra. En ese caso, la estrategia adecuada era demonizar todas esas manifestaciones para anularlas como herramientas de proselitismo. De esta manera, se comprueba el carácter inherentemente histórico del discernimiento de espíritus, así como la necesidad de estudiarlo sin perder de vista tanto el panorama más amplio de la teología que lo sustenta, como el contexto específico en el que se desarrolla. Como advirtiera

16 Quizás por ello, una vez terminado el proceso bélico-revolucionario, el pensador inglés Méric Casaubon (1599-1671), cuya lealtad se había mantenido hacia el bando realista, publicó Treatise Concerning Enthusiasme (1655), texto en el que vinculó explícitamente el misticismo católico con el fanatismo protestante. A los ojos de un moderado como él, los misioneros papistas y los visionarios y profetas de las sectas protestantes eran idénticos (Apetrei, 2015, p. 121). 
Sluhovsky, el discernimiento era una práctica social que respondía a un proceso de negociación antes que una teología fija e inmutable (Sluhovsky, 2007, p. 7).

\section{REFERENCIAS BIBLIOGRÁFICAS}

Almond, P. (2004). Demonic Possession and Exorcism in Early Modern England. Contemporary texts and their Cultural Contexts. Cambridge: Cambridge University Press. https://doi.org/10.1017/CBO9780511483417

Almond, P. (2012). The Lancashire Witches. A chronicle of sorcery and death on Pendle Hill. Londres-Nueva York: I. B Tauris \& Co. Ltd. https://doi. org/10.5040/9780755621132

Anon. (1597). The Most Wonderfull and true story of a certain Witch named Alice Gooderige, Londres (recopilado en: Almond, P. (2004). Demonic Possession and Exorcism in Early Modern England. Contemporary texts and their Cultural Contexts (pp. 150-192). Cambridge: Cambridge University Press.

Apetrei, S. (2015). Gender, mysticism, and enthusiasm in the British postreformation. Reformation \& Renaissance Review, 17(2), pp. 116-128. https://doi.org/10.117 9/1462245915Z.00000000074

Behringer, W. (2004). Witches and witch-hunts. A global history. Cambridge: Polity Press.

Bernard, R. (1627). A guide to grand iury men: divided into two books. Londres.

Bhogal, H. (2013) Rethinking Demonic Possession: The impact of the debates about the John Darrel case on later demonological thought, with particular reference to John Deacon and John Walker (tesis inédita de doctorado). Birbeck University of London.

Boddy, J. (1994). Spirit Possession Revisited: Beyond Instrumentality. Annu. Rev. Anthropol, 23, pp. 407-434. https://doi.org/10.1146/annurev. an.23.100194.002203

Bonzol, J. (2009). The Medical Diagnosis of Demonic Possession in an Early Modern English Community, Parergon, 26(1), pp. 115-140. https://doi.org/10.1353/ pgn.0.0132 
Boyer, P. y Nissembaum, S. (1993). Salem-Village Witchcraft: A Documentary Record of Local Conflict in Colonial New England. Boston: Northeastern University Press.

Caciola, N. (2003). Discerning Spirits. Divine and Demonic Possession in the Middle Ages. Ithaca y Londres: Cornell University Press.

Calvino, J. (1560). Institution de la Religion Chrétienne, 1560 (reedición de 1888, Librarie de la Suisse Française: París, 1888).

Cameron, E. (2012). Angels, Demons, and Everything in Between: Spiritual Beings in Early Modern Europe. En C. Copeland y J. Machielsen (eds.), Angels of Light? Sanctity and the Discernment of Spirits in the Early Modern Period (pp. 15-52). Leiden: Brill.

Campagne. F. (2003). Witchcraft and the Sense-of-the-Impossible in Early Modern Spain: Some Reflections Based on the Literature of Superstition (ca. 15001800). Harvard Theological Review, 96(1), pp. 25-62. https://doi.org/10.1017/ S0017816003000324

Campagne, F. (2009). Strix Hispánica. Demonología cristiana y cultura folklórica en la España moderna. Buenos Aires: Prometeo.

Campagne, F. (2014). Profetas en ninguna tierra. Una historia del discernimiento de espíritus en Occidente. Buenos Aires: Prometeo.

Clark, S. (1997). Thinking with Demons. The Idea of Witchcraft in Early Modern Europe. Oxford: Clarendon Press.

Clark, S. (2006). Demonology. En Golden, R (ed.), Encyclopedia of Witchcraft: The Western Tradition (pp. 259-263). California: ABC-Clio.

Clark. S. (2007). Vanities of the Eye. Vision in Early Modern European Culture. Oxford: Oxford University Press.

Cohn, N. (1975). Europe's Inner Demons: An Enquiry Inspired by the Great WitchHunt. Sussex y Londres: Sussex University Press and Heinemann Educational Books.

Cooper, T. (1617). The mystery of witchcraft. Londres. 
Copeland, C. y Machielsen, J. (2012). Introduction. En Copeland, C y Machielsen, J. (eds.), Angels of Light? Sanctity and the Discernment of Spirits in the Early Modern Period (pp. 1-16). Leiden: Brill. https://doi.org/10.1163/9789004233706_002

Cotta, J. (1625). The infallible, true and assured witch: or the second edition of the tryall of witchcraft: shewing the right and true method of the Discoverie. Londres.

Darrell, J. (1599). A brief apologie prouing the possession of William Sommers. Londres.

Darrell, J. (1600). A true narration of the strange and greuous vexation by the Devil, of seven persons in Lancashire. Londres.

De Waardt, Hans (2009). Jesuits, Propaganda and Faith Healing in the Dutch Republic. History, 94, pp. 344-359. https://doi.org/10.1111/j.1468-229X.2009.00459.x

del Olmo, I. (2018), Legio: Posesión diabólica y exorcismo en la Europa de los siglos XVI y XVII. Zaragoza: Institución Fernando el Católico.

Eire, C. (2003). War Against the Idols. The Reformation of Worship from Erasmus to Calvin. Cambridge: Cambridge University Press.

Eliav-Feldon, M. (2012), Renaissance Impostors and Proofs of Identity. Nueva York: Palgrave Macmillan. https://doi.org/10.1057/9781137291370

Elliott, D. (2012). Raptus/Rapture. En A. Hollywood y P. Beckman (eds.), The Cambridge Companion to Christian Mysticism (pp. 189-199). Cambridge: Cambridge University Press. https://doi.org/10.1017/CCO9781139020886.013

Fairfax, E. (1621), Daemonologia. Londres (reedición de 1882: Londres: B. Ackrill).

Ferber, S. (2004). Demonic Possession and Exorcisms in Early Modern France. Londres: Routledge.

Gaskill, Malcolm (2005). Witchfinders: A Seventeenth Century English Tragedy. Londres: John Murray.

Gibson, M. (1999). Reading Witchcraft. Stories of Early English Witches. Londres: Routledge. 
Gibson, M. (2006). Possession, Puritanism and Print. Londres: Pickering and Chatto.

Gifford, G. (1587). A Discourse of the Subtill Practises of Devills by Witches and Sorcerers. Londres.

Gifford, G. (1593). A Dialogue Concerning Witches and Witchrafts, Londres, 1593 (reedición de 1843: Londres: The Percy Society).

Gillespie, R. (2006). Imagining Angels in Early Modern England. En Marshall, P y Walsham, A (eds.), Angels in the Early Modern World (214-232). Cambridge: Cambridge Univeristy Press.

Ginzburg, C. (1989). Storia notturna: Una decifrazione del Sabba. Turín: Einaudi.

Holland, H. (1590). A treatise against witchcraft: or, a dialogue, wherein the greatest doubts concerning that sinne, are briefly answered. Londres.

Howells, E. (2012). Early Modern Reformations. En A. Hollywood y P. Beckman (eds.), The Cambridge Companion to Christian Mysticism (pp. 114-136). Cambridge: Cambridge University Press. https://doi.org/10.1017/CCO9781139020886.006

Johnstone, N. (2006). The Devil and Demonism in Early Modern England. Cambridge: Cambridge University Press. https://doi.org/10.1017/CBO9780511495847

Keck, D. (1998). Angels and angelology in the Middle Ages. Oxford: Oxford University Press.

Kieckhefer, R. (1979). European Witch Trials: Their Foundations in Popular and Learned Culture, 1300-1500. California: University of California Press.

Levack, B. (2006), The Witch Hunt in Early Modern Europe. Nueva York: Routledge.

Levack, B. (2013a). The Oxford Handbook of Witchcraft in Early Modern Europe and Colonial America. Oxford: Oxford University Press. https://doi.org/10.1093/ oxfordhb/9780199578160.001.0001

Levack, B. (2013b). The Devil Within. Possession \& Exorcism in the Christian West. Nueva Haven y Londres: Yale University Press. 
Macfarlane, A. (1970). Witchcraft in Tudor and Stuart England: A Regional and Comparative Study. Londres: Harper \& Row. https://doi. org/10.4324/9780203259481

Machielsen, J. (2020). Introduction. En J. Machielsen (ed.), The Science of Demons (pp. 1-16). Londres y Nueva York: Routledge, 2020. https://doi. org/10.4324/9780203702512-101

Mack, P. (1992). Visionary Women: Ecstatic Prophecy in SeventeenthCentury England. Los Angeles, University of California Press. https://doi. org/10.1525/9780520915589

Méndez, A. (2020). El infierno está vacío. Demonología, caza de brujas y reforma en la Inglaterra temprano-moderna. Valencia: Publicacions Universitat de Valencia.

Millar, C. R. (2017). Witchcraft, the Devil, and Emotions in Early Modern England. Londres y Nueva York: Routledge. https://doi.org/10.4324/9781315547015

Monter, W. (1976), Witchcraft in France and Switzerland: The Borderlands during the Reformation. Cornell: Cornell University Press.

Montesano, M. (2020), Witchcraft, Demonology and Magic. Basilea: MDPI.

Moore, M. (1650). Wonderful Newes from the north, Londres (recopilado en: Almond, P. (2004), Demonic Possession and Exorcism in Early Modern England. Contemporary texts and their Cultural Contexts (pp. 358-390). Cambridge: Cambridge University Press.

Muldoon, A. (2000). Recusants, Church-Papists, and 'Comfortable' Missionaries: Assessing the Post-Reformation English Catholic Community. The Catholic Historical Review, 86(2), pp. 242-257. https://doi.org/10.1353/cat.2000.0188

Norton, M.B. (2003). In the Devil's Snare: The Salem Witchcraft Crisis of 1692. Nueva York: Vintage.

Notestein, W. (1911). A History of Witchcraft in England from 1558 to 1718. Washington: American Historial Association.

Oldridge, D. (2010), The Devil in Tudor and Stuart England. Gloucestershire: The History Press. 
Ossa-Richardson, A. (2012). Gijsbert and Discretio Spirituum after Descartes. En C. Copeland y J. Machielse (eds.), Angels of Light? Sanctity and the Discernment of Spirits in the Early Modern Period (pp. 235-254). Leiden: Brill. https://doi. org/10.1163/9789004233706_010

Ossa-Richardson, A. (2013). The Devil's Tabernacle. The Pagan Oracles in Early Modern Thought. Princeton y Oxford: Princeton University Press.

Pearson, J. (2018). 'Much like the Picture of the Devill in a Play': Hypocrisy and Demonic Possession. En Nigri, L y Tsentourou, N (eds.), Forms of Hypocrisy in Early Modern England. Nueva York y Londres: Routledge. https://doi. org/10.4324/9781315265568-7

Perkins, W. (1608). A discourse of the damned Art of witchcraft. Londres.

Pitt-Rivers, J. (1991). Epílogo: el lugar de la gracia en la antropología. En J. Pitt-Rivers y J. G. Peristiany (eds.), Honor y gracia (pp. 280-321). Madrid: Alianza.

Purkiss, D. (1998). Invasions: Prophecy and Bewitchment in the Case of Margaret Muschamp. Tulsa Studies in Women's Literature, 17(2), pp. 235-253. https:// doi.org/10.2307/464387

Roberts, A. (1616). A Treatise of Witchcraft. Londres.

Rosen, B. (1991). Witchcraft in England 1558-1616. Amherst: University of Massachusetts Press.

Sands, K. (2004). Demon Possession in Elizabethan England. Londres: Preaeger.

Sangha, L. (2012). 'Incorporeal Substances': Discerning Angels in Later SeventeenthCentury England. En C. Copeland y J. Machielsen (eds.), Angels of Light? Sanctity and the Discernment of Spirits in the Early Modern Period (pp. 255-278). Leiden y Boston: Brill. https://doi.org/10.1163/9789004233706_011

Schmidt, J. (2007). Melancholy and the Care of the Soul. Religion, Moral Philosophy and Madness in Early Modern England. Londres: Ashgate.

Scott, R. J (2012). Visions, Dreams, and the Discernment of Prophetic Passions: Sense and Reason in the Writings of the Cambridge Platonists and John Beale, 1640-60. En C. Copeland y J. Machielsen (eds.), Angels of Light? Sanctity and 
the Discernment of Spirits in the Early Modern Period (pp. 201-234). Leiden y Boston: Brill. https://doi.org/10.1163/9789004233706_009

Sharpe, J. (1630). The triall of the protestant priuate spirit. Saint-Omer.

Sharpe, J. (1996). Instruments of Darkness. Witchcraft in England 1550-1750. Londres: Penguin.

Sluhovsky, M. (1991), Calvinist Miracles and the Concept of the Miraculous in Sixteenth-Century Huguenot Thought. Renaissance and Reformation / Renaissance et Réforme, 19 (2), pp. 5-25. https://doi.org/10.33137/ rr.v31i2.11609

Sluhovsky, M. (2007). Belive Not Every Spirit. Possession, Mysticism, \& Discernment in Early Modern Catholicism. Chicago: Chicago University Press. https://doi. org/10.7208/chicago/9780226762951.001.0001

Tausiet, M. (2014). Urban Magic in Early Modern Spain. Abracadabra Omnipotens. Nueva Hampshire y Nueva York: Palgrave Macmillan. https://doi. org/10.1057/9781137355881

Thomas, K. (1971). Religion and the Decline of Magic. Studies in the Popular Beliefs in Sixteenth and Seventeenth Century England. Londres: Penguin.

Uszkalo, K. (2015). Bewitched and Bedeviled. A Cognitive Approach to Emboodiment in Early Modern Possession. Nueva York: Palgrave Macmillan. https://doi. org/10.1057/9781137498229

Van Dijkhuizen, J. F. (2009), Theatricality, Inwardness and the Demonic in Ben Jonson. En H. De Waardt et al. (eds.), Dämonische Besessenheit. Zur Interpretation eines kulturhistorischen Phänomens (pp. 145-162). Bielefeld.

Walsham, A. (2003a). Providence in Early Modern England. Oxford: Oxford University Press.

Walsham, A. (2003b). Miracles and the Counter-Reformation Mission to England. The Historical Journal, 46(4), pp. 779-815. https://doi.org/10.1017/ S0018246X03003303

Walsham, A. (2005). Miracles in Post-Reformation England. Studies in Church History, 41, pp. 273-306. https://doi.org/10.1017/S0424208400000267 
Walsham, A. y Marshall, P. (2006). Migrations of angels in the Early Modern World. En P. Marshall y A. Walsham (eds.), Angels in the Early Modern World (pp. 1-40). Cambridge: Cambridge University Press.

Williams, G. (2006). Demonologies. En B. Levack (ed.), The Oxford Handbook of Witchcraft in Early Modern Europe and Colonial America (pp. 69-83). Oxford: Oxford University Press. 